\title{
A case of recurrent complex regional pain syndrome accompanying Raynaud's disease: a prospective coincidence?
}

\author{
Raynaud hastalı̆̆ına eşlik eden kompleks bölgeselağrı sendromu olgusu: \\ Beklenen bir birliktelik mi?
}

Serdar KESIKBURUN,' Zafer GÜNENDi, ${ }^{2}$ Koray AYDEMIR,' Ahmet ÖZGÜL,' Arif Kenan TAN'

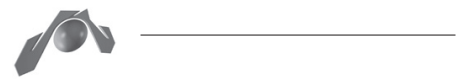

\begin{abstract}
Summary
Complex regional pain syndrome (CPRS) and Raynaud's disease are disorders characterized by vasomotor disturbances associating with abnormal autonomic nervous system. We present a case of CRPS involving a history of recurrence and no initiating event. Raynaud's disease accompanying CRPS was diagnosed clinically in the patient. We propose that a sympathetic dysfunction underlies the pathophysiologies of both disorders and may be responsible for the coexistence of these two distinct entities. Recurrence and unknown etiology of CRPS might account for temporary alterations in sympathetic function.
\end{abstract}

Key words: Complex regional pain syndrome; Raynaud's disease; sympathetic dysfunction.

\begin{abstract}
Özet
Kompleks bölgesel ağrı sendromu (KBAS) ve Raynaud hastalığı anormal otonom sinir sistemi ile ilişkili vazomotor bozuklukla kendini gösteren bir hastalıtır. Bu yazıda, herhangi bir başlatıcı olay olmadan gelişen ve tekrarlayıcı özelliği olan bir KBAS I olgusu sunuldu. Hastada ayrıca klinik olarak KBAS I'e eşlik eden Raynaud hastalığı tanısı da konuldu. Bu iki ayrı antitenin birlikteliğinden, her iki hastalı̆̆ında patofizyolojisinde yer alan, altta yatan bir sempatik disfonsiyonun sorumlu olabileceği düşünülmüştür. KBAS I'in tekrarlamast ve herhangi bir etyolojik faktör olmadan ortaya çııışı, sempatik disfonksiyonda meydana gelen geçici değişiklikler ile açılanabilir.
\end{abstract}

Anahtar sözcükler: Kompleks bölgesel ağrı sendromu; Raynaud hastalığl; sempatik disfonksiyon.

\section{Introduction}

Complex regional pain syndrome (CRPS) type I, formerly called reflex sympathetic dystrophy, is a clinical entity characterized by the presence of allodynia or hyperalgesia, edema, sweating changes, abnormal skin color and temperature, trophic changes of nails and hairs and often impairment of motor function in the affected extremity. The pain in CRPS is disproportionate to any inciting event. The history of an initiating noxious event such as trauma exists commonly. How- ever, 5-10\% of patients can have an obscure etiology. [1] Raynaud's phenomenon is an episodic vasospasm of peripheral arteries, triggered by exposure to cold and emotional stress. ${ }^{[2]}$ This exaggerated vasospastic response causes the pallor of digits, followed by cyanosis and finally a hyperemia which may be lacking. ${ }^{[3]}$ Autonomic nervous system disturbances contribute to mechanisms of both disorders which are represented by an altered mechanism of vasal motility. ${ }^{[4]}$

\footnotetext{
'Department of Physical Medicine and Rehabilitation, Gülhane Military Medical Academy, Turkish Armed Forces Rehabilitation Center, Ankara ${ }^{2}$ Department of Physical Medicine and Rehabilitation, Gazi University Faculty of Medicine, Ankara, Turkey

'Gülhane Askeri Tıp Akademisi, Fiziksel Tıp ve Rehabilitasyon Anabilim Dalı, Türk Silahlı Kuvvetleri Rehabilitasyon Merkezi, Ankara ${ }^{2}$ Gazi Üniversitesi Tıp Fakültesi, Fiziksel Tıp ve Rehabilitasyon Anabilim Dalı, Ankara

Submitted (Başvuru tarihi) 02.12.2010 Accepted after revision (Düzeltme sonrası kabul tarihi) 30.11.2011
}

Correspondence (IIletişim): Serdar Kesikburun, M.D. Türk Silahlı Kuvvetleri Rehabilitasyon Merkezi, Bilkent, 06530 Ankara, Turkey.

Tel: +90 - 312-291 1707 e-mail (e-posta): serdarkb@gmail.com 
We present a case of recurrent and idiopathic CRPS type I accompanying Raynaud's disease. The coincidence of these two entities may be postulated to result from an individual disease of sympathetic nervous system which contributes to both pathophysiologies of disorders.

\section{Case Report}

A 21-year-old male patient with pain, swelling and cyanosis of his right hand was admitted to our department. There was no history of trauma that might have triggered these complaints. He had suffered from similar complaints with the same hand one year earlier and it had improved spontaneously within three weeks. In physical examination, his right hand and fingers were edematous and cold, also had a cyanotic appearance (Figure 1a). He had allodinia and hyperlgesia in response to touch on the dorsum of his hand and fingers. The skin of his right hand was dry and the nails of his right fingers were dystrophic. These clinical findings were consistent with CPRS type I. It was also detected by physical examination that his left fingers and bilateral toes were cyanotic and cold (Figure 1b). The cyanosis of the fingers and the toes had recurred once or twice a month for a few years and had been exacerbated by cold, which were suggestive for Raynaud's phenomenon. His plain radiograph, electromyography and doppler flowmetry, performed for differential diagnosis, were normal. His nailfold capillaroscopy and immunological tests of antinuclear antibody, erythrocyte sedimentation rate, C-reactive protein, performed to rule out possible underlying conditions, were normal. Based on these clinical and lab- oratory findings, primary Raynaud's phenomenon (Raynaud's disease) accompanying CRPS type I was diagnosed. A three-week-rehabilitation program including range of motion and stretching exercises (30 minutes a day), contrast bath therapy (15 minutes a day) and TENS-therapy (20 minutes a day) was introduced. He responded well to physical therapy, his pain and swelling in the hand resulting from CRPS type I improved within three weeks. As the frequency of cyanosis of his fingers and toes reduced by avoiding cold, any pharmacological treatment was not considered for Raynaud's phenomenon.

\section{Discussion}

The IASP CRPS criteria include continuing pain disproportionate to any inciting event and four distinct diagnostic categories. The four categories are recognized as sensory findings including hyperesthesia, allodynia, hyperalgesia; vasomotor findings including temperature and/or skin color asymmetry; sudomotor findings including edema and/or sweating changes; motor/trophic findings including decreased range of motion, motor dysfunction (weakness, tremor, dystonia), trophic changes of hair, nail, skin. Clinical diagnostic decision rules are endorsed as the presence of signs observed by the physician on clinical examination in two or more of these categories and symptoms reported by the patient in at least three of four categories. ${ }^{[1]}$ In our case, symptoms and signs in all four categories were positive. There were also informative tests and procedures that are not specific for the diagnosis of CRPS such as infrared thermography, quantitative sensory testing, sudomotor tests, bone scintipraphy and $\mathrm{x}$-ray (spotty osteoporosis). ${ }^{[5]}$
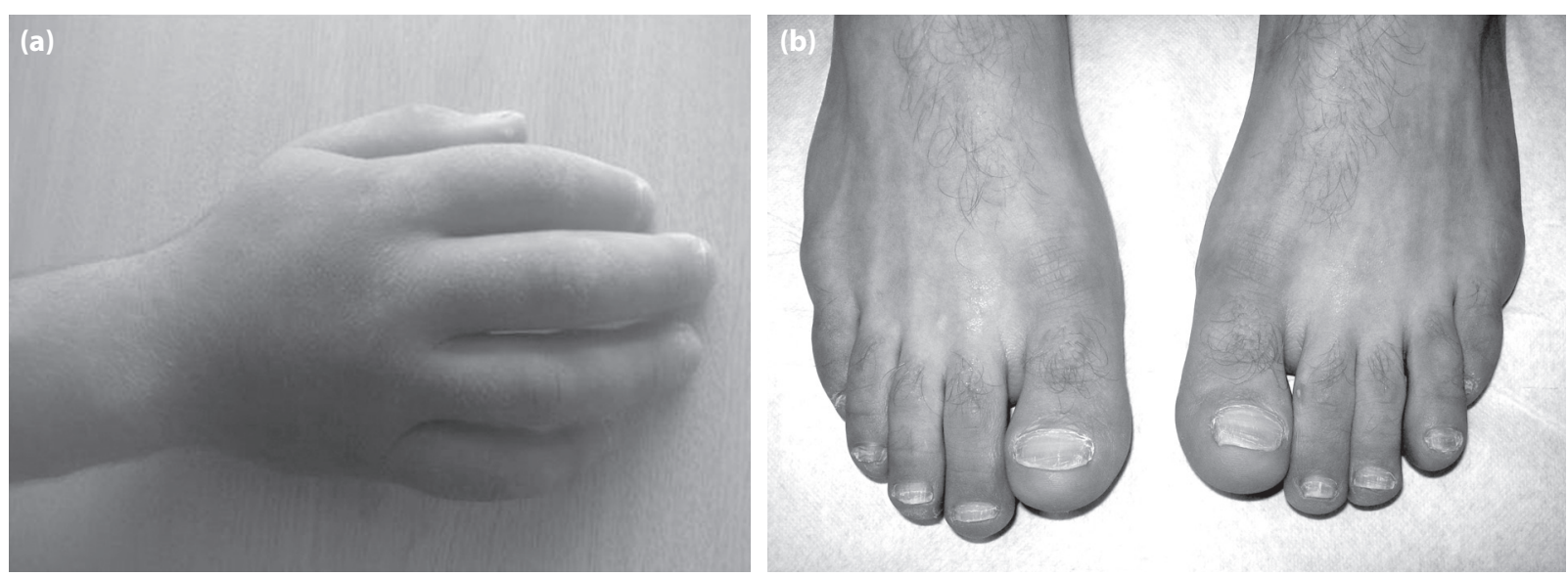

Figure 1. (a) Figure shows edematous and cyanotic right hand with dry and scaly skin. (b) Figure shows cyanosis of toes. 
The pathophysiological mechanisms of CRPS are based on the posttraumatic regional inflammation, that sensitizes $\mathrm{C}$-nociceptive fibers and leads to release of some vasoactive neuropeptides, and the sympathetic dysfunction. ${ }^{[5]}$ Vasomotor and sudomotor changes in CRPS are the indicator of autonomic dysfunction. Deteriorated peripheral vasoconstrictor responses after sympathetic stimulation in CRPS I patients have recently been detected not only during acute and early phase, but also before the onset of the disease and even after years in a chronic state of the disease. ${ }^{[6,7]}$ Accordingly it is theorized that the patients who develop CRPS I may have an underlying sympathetic nervous system abnormality which may recover to a certain extent during the course of the disease. ${ }^{[6]}$

Abnormality in the sympathetic nervous system which controls thermoregulation contributes to the pathological pathways of Raynaud's phenomenon as well. ${ }^{[2]}$ In the study of Herrick et al. asymptomatic thermoregulatory abnormalities in noninvolved limbs of CRPS I patients were detected by defective response to cold challenge. ${ }^{[8]}$ All these knowledge suggest the presence of similar sympathetic dysfunction in the pathophysiology of both Raynaud's phenomenon and CRPS. In addition, sympathectomy was found beneficial in the treatment of both disorders. ${ }^{[4]}$

In the light of this pathophysiology knowledges, it may be suggested that an autonomic disturbance in the patient account for the coexistence of these two entities. A likely individual defect in sympathetic nervous system may contribute to occur both primary Raynaud's phenomenon and CRPS I in the patient who don't have history of trauma or any initiating factor. CRPS I recurred two times apart one year in our case. Recurrence might be due to temporary alterations and relapsing in individual sympathetic dysfunction. There are two more reported cases of idiopathic and recurrent CRPS I which have also a migratory characteristic. ${ }^{[9,10]}$ These were not discussed in terms of possible explanations for unidentified etiology and recurrence.

Primary goal of the treatment in CRPS is functional restoration. Specific exercise therapy is the most essential part of the treatment. Therapeutic cold and heat, TENS-therapy, contrast bath and occupa- tional therapy are the others component of physical therapy. The pharmacological treatment includes nonsteroidal anti-inflammatory drugs, glucocorticoids, calcitonin, opioids, tricyclic antidepressants, membrane stabilizers (carbamazepin, gabapentin, lidocain, mexiletin), NMDA-receptor antagonists (ketamin), GABA-agonists (baclofen), adrenoceptor antagonists (clonidin, phentolamin) and topical capsaicin. Sympathetic ganglion block with local anesthetics and continuous conduction block of brachial or lumbar plexus form the regional anesthetic techniques. Neuromodulation with spinal stimulation and behavioral therapy are the remaining alternatives in the treatment. The physical therapy program we planned for our patient included exercise, contrast bath, TENS-therapy. The patient's complaints relieved with this program. ${ }^{[5]}$

To conclude, our case of recurrent and idiopathic CRPS I accompanying Raynaud's disease is the first one reported in the literature. Recurrence and unknown etiology of CRPS I in our case may be explained by an underlying sympathetic nervous system abnormality which exacerbates temporarily.

\section{References}

1. Harden RN, Bruehl SP. Diagnosis of complex regional pain syndrome: signs, symptoms, and new empirically derived diagnostic criteria. Clin J Pain 2006;22(5):415-9. [CrossRef]

2. Herrick AL. Pathogenesis of Raynaud's phenomenon. Rheumatology (Oxford) 2005;44(5):587-96. [CrossRef]

3. Gayraud M. Raynaud's phenomenon. Joint Bone Spine 2007;74(1):e1-8. [CrossRef]

4. Rizzo M, Balderson SS, Harpole DH, Levin LS. Thoracoscopic sympathectomy in the management of vasomotor disturbances and complex regional pain syndrome of the hand. Orthopedics 2004;27(1):49-52.

5. Vacariu G. Complex regional pain syndrome. Disabil Rehabil 2002;24(8):435-42. [CrossRef]

6. Vogel T, Gradl G, Ockert B, Pellengahr CS, Schürmann M. Sympathetic dysfunction in long-term complex regional pain syndrome. Clin J Pain 2010;26(2):128-31. doi: 10.1097/ AJP.0b013e3181b5effc. [CrossRef]

7. Gradl G, Schürmann M. Sympathetic dysfunction as a temporary phenomenon in acute posttraumatic CRPS I. Clin Auton Res 2005;15(1):29-34. [CrossRef]

8. Herrick A, el-Hadidy K, Marsh D, Jayson M. Abnormal thermoregulatory responses in patients with reflex sympathetic dystrophy syndrome. J Rheumatol 1994;21(7):1319-24.

9. Akkus $\mathrm{S}$, Yorgancigil $\mathrm{H}$, Yener M. A case of recurrent and migratory complex regional pain syndrome type I: Prevention by gabapentin. Rheumatol Int 2006;26(9):852-4. [CrossRef]

10. Tong HC, Nelson VS. Recurrent and migratory reflex sympathetic dystrophy in children. Pediatr Rehabil 2000;4(2):87-9. 